\title{
PACIENTŲ EMOCINĖS IR FUNKCINĖS BŪKLĖS KAITA PO ESTETINIO PROTEZAVIMO
}

\author{
Jovita Liškutė, Rasa Tamulienė, Daiva Mačiulienė \\ Kauno kolegija
}

Raktažodžiai: estetinis protezavimas, emocinẻ būklè, funkcinè būklè.

\begin{abstract}
Santrauka
Šiandien vis didesnis demesys skiriamas ne tik èduonies pažeistiems dantims, tačiau ir jų estetinei išvaizdai. Mokslinejje literatūroje akcentuojama, jog graži šypsena yra svarbi socialinė vertybė ir lemia paciento ne tik funkcinès, tačiau ir emocinès būklès pokyčius.

Tyrimo tikslas: nustatyti pacientų emocinès ir funkł cinès būklès kaitą po estetinio protezavimo procedūros.

Tyrimo dalyviai ir metodai: 48 pacientai, kuriems buvo atlikta estetinio protezavimo procedūra. Taii kytas duomenų rinkimo metodas - apklausa raštu. Tyrimo rezultatai: atlikto tyrimo rezultatai parodè, kad po estetinio protezavimo procedūros labiau pasikeitè pacientų emocinè nei funkcinè būklè. Tyrimo rezultatai atskleide, kad pacientai, kuriems buvo atlikta estetinio protezavimo procedūra, pradèjo labiau pasitikèti savimi, atsirado pojūtis, jog gyvenimas yra geresnis ir pilnavertiškesnis, tyrimo dalyviai pradejo skirti daugiau dèmesio burnos higienai. Vertinant funkcinès būklès pokyčius nustatyta, kad labiausiai pasikeitė kramtymo bei sukandimo funkcijos.
\end{abstract}

\section{Ivadas}

Šiandien vis didesnis demesys skiriamas ne tik ėduonies pažeistiems dantims, tačiau ir jų estetinei išvaizdai. Amee rikoje atliktas tyrimas [3] parodè, kad 99,7 \% respondentu teigia, kad graži šypsena yra svarbi socialinè vertybè, $96 \%$ - kad graži šypsena labiau patraukia priešingos lyties atstovus, $74 \%$ - kad nepatraukli šypsena sumažina karjeros sèkmę. Tik $50 \%$ amerikiečių yra patenkinti savo dabartine šypsena. Teigiama, kad žmonès, turintys patrauklią šypseną ar gražius dantis, patys to nesuprasdami pradeda elgtis ir jaustis kitaip, jie tampa nuoširdesni, dèkingesni
[1]. Po estetinio protezavimo procedūru pacientai pradeda laisviau bendrauti, nes nebejaučia diskomforto šypsantis, šios procedūros padeda žmonėms pasijusti patrauklesniems. Teigiama, kad graži šypsena daro teigiamą poveiki pacientu socialiniam, psichologiniam ir emociniam gyvenimui [4]. Atlikti tyrimai [5] rodo, kad po estetinio protezavimo procedūros taip pat pasikeičia pacientu požiūris i burnos ertmès priežiūrą. Atlikus estetinio protezavimo procedūras pacientai pradeda daugiau dèmesio skirti individualiai ir profesionaliai burnos higienai [5].

Mokslinėje literatūroje akcentuojama, jog graži šypsena yra svarbi socialinè vertybė $[1,3,4$,] ir lemia ne tik funkcinès, tačiau ir emocinès paciento būklès pokyčius, vis dèlto lieka neaišku, kokius - emocinius ar funkcinius - pokyčius pacientai labiau jaučia po estetinio protezavimo procedūros ir kokie yra konkretūs emocinès ir funkcinès būklès pokyčiai. Straipsnyje pristatomame tyrime keliamas probleminis klausimas - kaip keičiasi pacientų emocinè ir funkcinè būklè po estetinio protezavimo procedūros, remiantis jų nuomone? Tyrimo objektas - pacientų nuomonè apie emocinès ir funkcinès būklès kaitą po estetinio protezavimo.

Tyrimo uždaviniai: nustatyti pacientų emocinę būklę prieš ir po estetinio protezavimo procedūros, remiantis jų nuomone; nustatyti pacientų funkcinę būklę prieš ir po estetinio protezavimo procedūros, remiantis jų nuomone.

Estetinis protezavimas ir veiksniai lemiantys jo poreikị. Dantų protezavimo pagrindinis tikslas yra atkurti trūkstamus dantis arba pagerinti esamų dantų būklę. Iprastai dantu protezavimas atliekamas, kai danties audiniai yra pažeiti ėduonies, kai dantys yra nudilę ar nukentejję dèl ligos ar traumos. Priežasčių, kodèl reikia protezuoti, yra labai daug, bet estetinis protezavimas atlieka kitokią funkciją - jis dažniausiai atliekamas priekinių dantų srityje norint pakoreguoti jų formą, spalvą ar uždaryti tarpus tarp dantų [6]. Estetinis protezavimas pasirenkamas tada, kai danties audinių defektai yra dideli ir jiems atkurti nebeužtenka plombinès medžiagos [6]. Esant dantų nusidèvejjimui, nuskilimui, negydytam kariesui ar sergant 
sisteminemis ligomis, galima pasirinkti gydymą, kuris išsaugotu kuo daugiau sveiku danties audinių. Priklausomai nuo defekto dydžio ir esamos situacijos parenkamos tinkamiausios restauracijos. Plačiai paplitę danties audinių defektai, ittraukiant estetinius trūkumus, sukeliami patologinio vystymosi, veikant lètiniams veiksniams, taip pat trauminių sužalojimų ir kitų dantų ligų.

Sveiki dantys pažeidžiami dèl daugelio priežasčių ir bendras poveikis yra žalingas. Kai dantis ar danties paviršius yra pažeidžiamas ir atsiranda defektas, kyla grèsmè, nes audiniai savarankiškai negali regeneruoti. Todèl dirbtiniai dantų pakaitalai, kitaip dar žinomi kaip dantų protezai, yra reikalingi atkurti pažeistus, neestetiškus ar nebefunkcionuojančius dantis, audinius ar visiškai atkurti vieną, daugiau prarastų dantų. Dažniausiai naudojami dantų protezai skirti èduonies pažeistiems dantims, turintiems pilną ar dalinį defektą [7]. Pacientai, kuriems yra atliekamos estetinio protezavimo procedūros, paprastai yra pacientai, kurie per savo gyvenimą turèjo nuolatinių problemų, susijusių su dantu kariesu. Nors ir atkūrus defektus restauraciniais būdais, laikui bėgant, veikiant aplinkos veiksniams jie gali

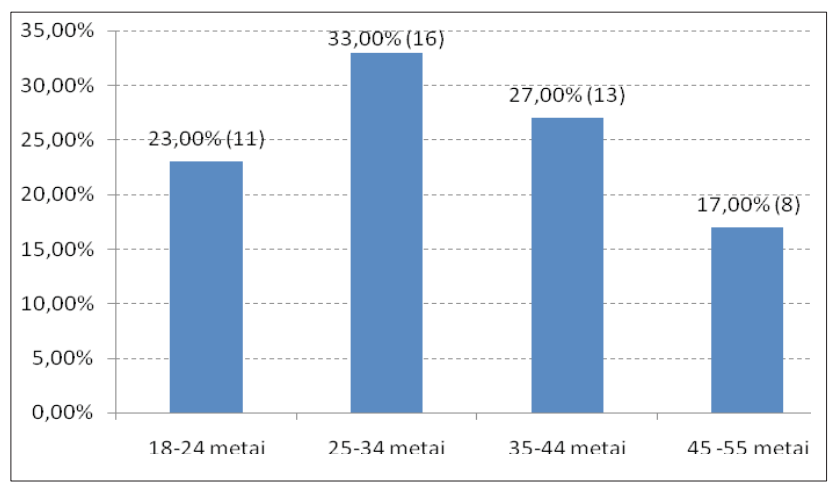

1 pav. Tyrimo dalyvių pasiskirstymas pagal amžių $(\mathrm{N}=48)$

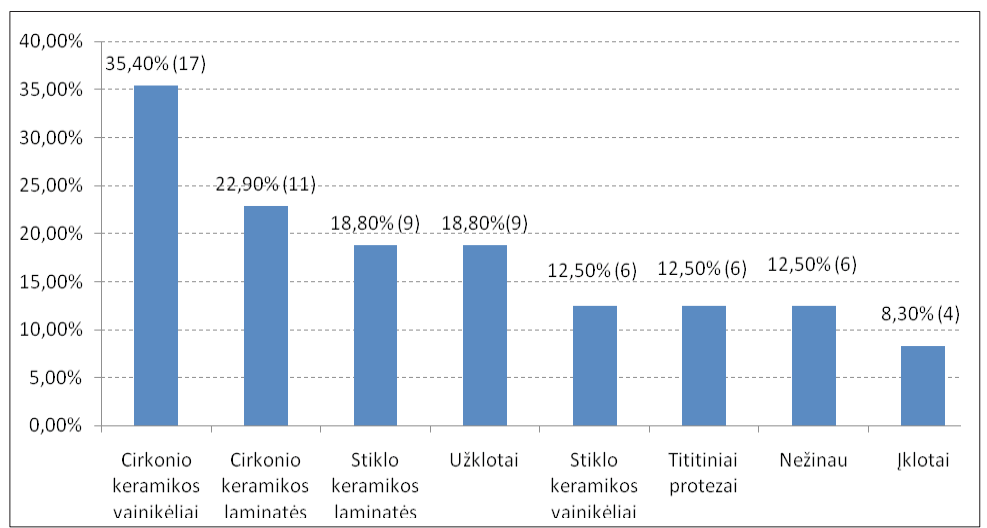

2 pav. Tyrimo dalyvių pasiskirstymas pagal protezavimo būdą $(\mathrm{N}=48)$ deformuotis, vystosi antrinis kariesas. Apie 70\% restauracijų odontologijoje yra atliekama keičiant senesnes restauracijas [2].

Estetinio protezavimo procedūros dažniausiai atliekamos pacientams patyrus dantų traumą, dèl antibiotiko tetraciklino sukeltų dantų spalvos patamsèjimų, geriamojo vandens, kuriame fluoro lygis yra didesnis nei iprastai, sukeltos fluorozès ar karieso [7, 8].

Tyrimo tikslas - nustatyti pacientų emocinès ir funkcinès būklès kaitą po estetinio protezavimo procedūros, remiantis jų nuomone.

\section{Tyrimo objektas ir metodika}

Tyrimas vyko nuo 2015 metu vasario 6 iki kovo 31 dienos. Privačiose Kauno miesto klinikose buvo išdalintos 93 anketos pacientams, kuriems buvo ketinama atlikti estetinio protezavimo procedūrą. Tolimesniam tyrimui buvo atrinktos tik 48 anketos, nes likusios anketos buvo negrąžintos po atliktos procedūros arba užpildytos netinkamai. Anketų grižtamumas 51,6\%. Taikytas imties sudarymo būdas: netikimybinè proginè.

Atliekant tyrimą buvo laikomasi konfidencialumo, informuoto sutikimo ir laisvo apsisprendimo dalyvauti tyrime etikos nuostatų.

Tyrimo metu naudotas duomenų rinkimo metodas - apklausa raštu, tyrimo instrumentas - klausimynas. Klausimynas buvo sudarytas tyrimo autorių iš trijų klausimų blokų. Pirmasis klausimų blokas buvo skirtas pacientų emocinès būklès ịvertinimui (vertinti kriterijai: pasitikèjimas savimi, komunikabilumas, nuotaika, pilnavertiškesnio gyvenimo pojūtis, požiūris ị burnos higieną); antrasis - funkcinès būklès ịvertinimui (vertinti kriterijai: kramtymas, sukandimas, virškinimas, kalbėjimas, griežimas dantimis). Pirmojo bei antrojo bloko klausimuose tyrimo dalyviams buvo pateikti teiginiai apie funkcinę ir emocinę būklę prieš ir po estetinio protezavimo procedūros, kuriuos jie turejjo įvertinti nuo 1 iki 5 (kai 1 reiške, jog pokyčiai yra minimalūs, o 5 - ženkliai pastebimi). Trečiajame klausimų bloke buvo pateikti kontekstinio tipo klausimai (tiriamujų lytis, amžius, estetinio protezavimo būdas, protezuotų dantų skaičius ir kt.).

Tyrimo rezultatų duomenų analizei atlikti buvo naudojama statistinè duomenų analizè, t.y., aprašomosios statistikos, dažnių bei vidurkių skaičiavimai, porinis t kriterijus.

Tyrime dalyvavo 48 pacientai. Tyrimo dalyviai pagal lytị pasiskirtè taip: 69 proc. - moterys, 31 proc. - vyrai. Dalyvaujančių respondentų amžius pasiskirstė nuo 18 iki 55 metų amžiaus 
(1 paveikslas). Kaip matyti pirmame paveiksle, didesnioji dalis tyrime dalyvavusiu pacientu yra 25-34 (33 proc.) ir 35-44 (27 proc.) metu amžiaus (1 paveikslas).

Didžiajai daliai tyrimo dalyviu ( 35,4 proc.) estetinio protezavimo procedūra buvo atlikta naudojant cirkonio keramikos vainikèlius bei cirkonio keramikos laminates (22,9 proc.); mažiausiai (8,3 proc.) - iklotus (2 paveikslas). 12,5 proc. tyrimo dalyvių nurodè, jog nežino, koks protezavimo būdas jiems buvo taikytas (2 paveikslas).

Tyrimo „Pacientų emocinė ir funkcinė būklė prieš ir po estetinio protezavimo" rezultatai

Tyrimo rezultatai atskleidè statistiškai patikimą skirtumą $(\mathrm{p}<0.05)$ tarp pacientų emocinès ir funkcinès būklès prieš ir po estetinio protezavimo procedūros. Nustatyta, kad, remiantis tyrimo dalyvių nuomone, emocinè būklè (1, 32 vidurkių skirtumas) pakito labiau nei funkcinè ( 0,6 vidurkių skirtumas) (1 lentelè).

Pacientu emocinès būklès kaita po estetinio protezavimo procedūros. Vertinant pacientų emocinès būklès pokyčius po estetinio protezavimo procedūros nustatyta, kad statistiškai reikšmingai $(\mathrm{p}<0.05)$ pakito pacientu pasitikejimas savimi, komunikabilumas, nuotaika, pilnavertiškesnis gyvenimo pojūtis, požiūris i burnos higieną (2 lentelè).

1 lentelè. Tyrimo dalyvių emocinès ir funkcinès būklès kaita (balı ais) po estetinio protezavimo procedūros $(\mathrm{N}=48)$

\begin{tabular}{|l|c|c|c|c|}
\hline \multirow{2}{*}{ Būklė } & \multicolumn{4}{|c|}{ Estetinio protezvimo procedūra } \\
\cline { 2 - 5 } & Prieš & Po & $\begin{array}{c}\text { Vidurkiụ } \\
\text { skirtumas }\end{array}$ & p reikšmė \\
\hline Emocinė & 3,12 & 4,44 & $\mathbf{1 , 3 2}$ & $\mathbf{0 . 0 0 0}$ \\
\hline Funkcinè & 3,1 & 3,7 & $\mathbf{0 , 6}$ & $\mathbf{0 . 0 0 0}$ \\
\hline
\end{tabular}

Vertinant vidurkių skirtumus nustatyta, kad labiausiai pasikeitè pacientu pasitikejimas savimi (vidurkių skirtumas 1,5 ), atsirado pilnavertiškesnio gyvenimo pojūtis (vidurkiu skirtumas 1,31), tyrimo dalyviai pradèjo daugiau dèmesio teikti kasdieninei burnos higienai (vidurkių skirtumas 1,29) (2 lentelè).

Analizuojant pacientu emocinès būklès kaita priklausomai nuo aplinkinių reakcijos ị protezavimo procedūros rezultatą nustatyta, labiausiai pasikeitè tų pacientų emocinè būklè, kuriu pokyčius pastebejjo aplinkiniai (vidurkių skirtumas 1,51) (3 lentelè). Nustatyta, kad pacientų, kurių pokyčius pastebèjo aplinkiniai, labiausiai padidejo komunikabilumas (1,89 vidurkių skirtumas), pasitikèjimas savimi (1,54 vidurkių skirtumas), požiūris ị burnos higieną $(1,43)$.

Pacientai, kuriu pokyčius pastebèjo aplinkiniai, tačiau nesuprato, kas konkrečiai pasikeite jų išvaizdoje, nurodè,

2 lentelè. Tyrimo dalyviụ emocinè būklè prieš ir po estetinio protezavimo procedūros $(\mathrm{N}=48)$

\begin{tabular}{|l|c|c|c|c|}
\hline \multirow{2}{*}{ Emocinè būklè } & \multicolumn{3}{|c|}{ Estetinio protezvimo procedūra } \\
\cline { 2 - 5 } & Prieš & Po & $\begin{array}{c}\text { Vidurkių } \\
\text { skirtumas }\end{array}$ & $\begin{array}{c}\text { p reikš- } \\
\text { mé }\end{array}$ \\
\hline $\begin{array}{l}\text { Pasitikèjimas } \\
\text { savimi }\end{array}$ & 2,92 & 4,42 & 1,5 & 0.012 \\
\hline $\begin{array}{l}\text { Komunikabilu- } \\
\text { mas }\end{array}$ & 3,17 & 4,4 & $\mathbf{1 , 2 3}$ & $\mathbf{0 . 0 0 1}$ \\
\hline Gera nuotaika & 3,33 & 4,6 & $\mathbf{1 , 2 7}$ & $\mathbf{0 . 0 3 8}$ \\
\hline $\begin{array}{l}\text { Pilnavertiš- } \\
\text { kesnis gyveni- } \\
\text { mo pojūtis }\end{array}$ & 3,19 & 4,5 & $\mathbf{1 , 3 1}$ & $\mathbf{0 . 0 0 1}$ \\
\hline $\begin{array}{l}\text { Požiūris ị bur- } \\
\text { nos higieną }\end{array}$ & 2,98 & 4,27 & 1,29 & 0.000 \\
\hline
\end{tabular}

3 lentelè. Pacientų emocinès būklès (balais) ir aplinkinių reakcijos ị estetinio protezavimo procedūros rezultatą sąsajos $(\mathrm{N}=48)$

\begin{tabular}{|c|c|c|c|c|c|c|c|c|c|}
\hline \multirow[t]{2}{*}{ Emocinè būklè } & \multicolumn{3}{|c|}{$\begin{array}{c}\text { Aplinkiniai pastebèjo } \\
\text { pokyčius }\end{array}$} & \multicolumn{3}{|c|}{$\begin{array}{l}\text { Aplinkiniai pastebėjo } \\
\text { pokyčius, bet nesupra- } \\
\text { to, kas pasikeitė }\end{array}$} & \multicolumn{3}{|c|}{$\begin{array}{c}\text { Aplinkiniai pokyčiu } \\
\text { nepastebėjo }\end{array}$} \\
\hline & Prieš & Po & $\begin{array}{l}\text { Skirtu- } \\
\text { mas }\end{array}$ & Prieš & Po & $\begin{array}{l}\text { Skirtu- } \\
\text { mas }\end{array}$ & Prieš & Po & $\begin{array}{c}\text { Skirtu- } \\
\text { mas }\end{array}$ \\
\hline Pasitikejjimas savimi & 3,21 & 4,75 & 1,54 & 3,47 & 4,2 & 0,73 & 3,6 & 5 & 1,4 \\
\hline Komunikabilumas & 2,71 & 4,60 & 1,89 & 3,2 & 4 & 0,8 & 3,2 & 4,6 & 1,4 \\
\hline Gera nuotaika & 3,07 & 4,39 & 1,32 & 3,33 & 4,2 & 0,87 & 3,2 & 5 & 1,8 \\
\hline $\begin{array}{l}\text { Pilnavertiškesnis gy- } \\
\text { venimo pojūtis }\end{array}$ & 3,29 & 4,68 & 1,39 & 3 & 4,67 & 1,67 & 3,2 & 3,6 & 0,4 \\
\hline $\begin{array}{l}\text { Požiūris ị burnos hi- } \\
\text { gieną }\end{array}$ & 3,07 & 4,5 & 1,43 & 3 & 4,13 & 1,13 & 2,4 & 3,4 & 1 \\
\hline $\begin{array}{l}\text { Bendras emocinès bū- } \\
\text { klès vidurkis }\end{array}$ & 3,07 & 4,58 & 1,51 & 3,2 & 4,24 & 1,04 & 3,12 & 4,32 & 1,2 \\
\hline
\end{tabular}


kad labiausiai pasikeite tai, jog atsirado pojūtis, kad gyvenimas yra pilnavertiškesnis (vidurkių skirtumas 1,67). Atlikto tyrimo rezultatai atskleide, kad pacientai, kurių pokyčių išvaizdoje aplinkiniai nepastebèjo, nurodè, jog labiausiai pagerèjo jų nuotaika (vidurkių skirtumas 1,8) po estetinio protezavimo procedūros (3 lentelè).

Pacientu funkcinès būklès kaita po estetinio protezavimo procedūros. Vertinant pacientų funkcinès būklès kaitą po estetinio protezavimo procedūros nustatyta, kad po estetinio protezavimo procedūros statistiškai reikšmingai $(\mathrm{p}<0.05)$ pasikeite kramtymo, sukandimo, virškinimo, kalbejjimo ir griežimo dantimis funkcijos (4 lentelè). Viè

4 lentelè. Tyrimo dalyvių funkcinè būklè prieš ir po estetinio protezavimo procedūros $(\mathrm{N}=48)$

\begin{tabular}{|l|c|c|c|c|}
\hline \multirow{2}{*}{$\begin{array}{l}\text { Funkcinė } \\
\text { būklė }\end{array}$} & \multicolumn{4}{|c|}{ Estetinio protezvimo procedūra } \\
\cline { 2 - 5 } & Prieš & Po & $\begin{array}{c}\text { Vidurkių } \\
\text { skirtumas }\end{array}$ & p reikšmė \\
\hline Kramtymas & 2,88 & 3,75 & 0,87 & $\mathbf{0 . 0 2 4}$ \\
\hline Sukandimas & 2,81 & 3,63 & 0,82 & $\mathbf{0 . 0 0 1}$ \\
\hline Virškinimas & 3,17 & 3,5 & 0,33 & $\mathbf{0 . 0 0 0}$ \\
\hline Kalbejjimas & 3,25 & 3,85 & 0,6 & $\mathbf{0 . 0 0 1}$ \\
\hline $\begin{array}{l}\text { Griežimas dan- } \\
\text { timis }\end{array}$ & 3,42 & 3,81 & 0,39 & $\mathbf{0 . 0 0 0}$ \\
\hline
\end{tabular}

durkių skirtumų analizė atskleidè, kad labiausiai pakito kramtymo (vidurkių skirtumas - 0,87 ) ir sukandimo (vidury kių skirtumas - 0,82) funkcijos (4 lentelè).

Analizuojant tyrimo dalyvių funkcinès būklès pokyčius priklausomai nuo protezuotų dantų skaičiaus nustatyta, kad labiausiai pasikeitè tų pacientų funkcinè būklè, kuriems buvo protezuoti 1-2 dantys (vidurkių skirtumas - 0,8) bei pacientai, kuriems buvo protezuota 9 ir daugiau dantu (vidurkių skirtumas - 0,8) (5 lentelè). Penktoje lentelejje matyti, kad pacientų, kuriems buvo protezuota 9 ir daugiau dantų labiausiai pasikeite kramtymo funkcija (vidurkių skirtumas $-1,83)$ ir sukandimas (vidurkių skirtumas - 1,34) (5 lentelè).

\section{Diskusija}

Nors atliekant estetinio protezavimo procedūras dažniau akcentuojama funkcinès būklès kaita, vis dèlto tyrimo rezultatai atskleidè, kad pacientams yra reikšmingesnè emocinès būklès kaita. Tyrimo rezultatai atskleidè, kad pacientų emocinès būklès kaita yra susijusi su tuo, ar aplinkiniai pastebejjo dantų pokyčius po estetinio protezavimo procedūros. Nustatyta, kad pacientų, kurių pokyčius pastebèjo aplinkiniai, emocinè būklè pasikeitè labiau nei tų, kurių pokyčių nepastėbėjo ar pastebejjo, tačiau negalėjo įvar-

5 lentelė. Funkcinès būklès kaitos vidurkis (balais) priklausomai nuo protezuotų dantų skaičiaus

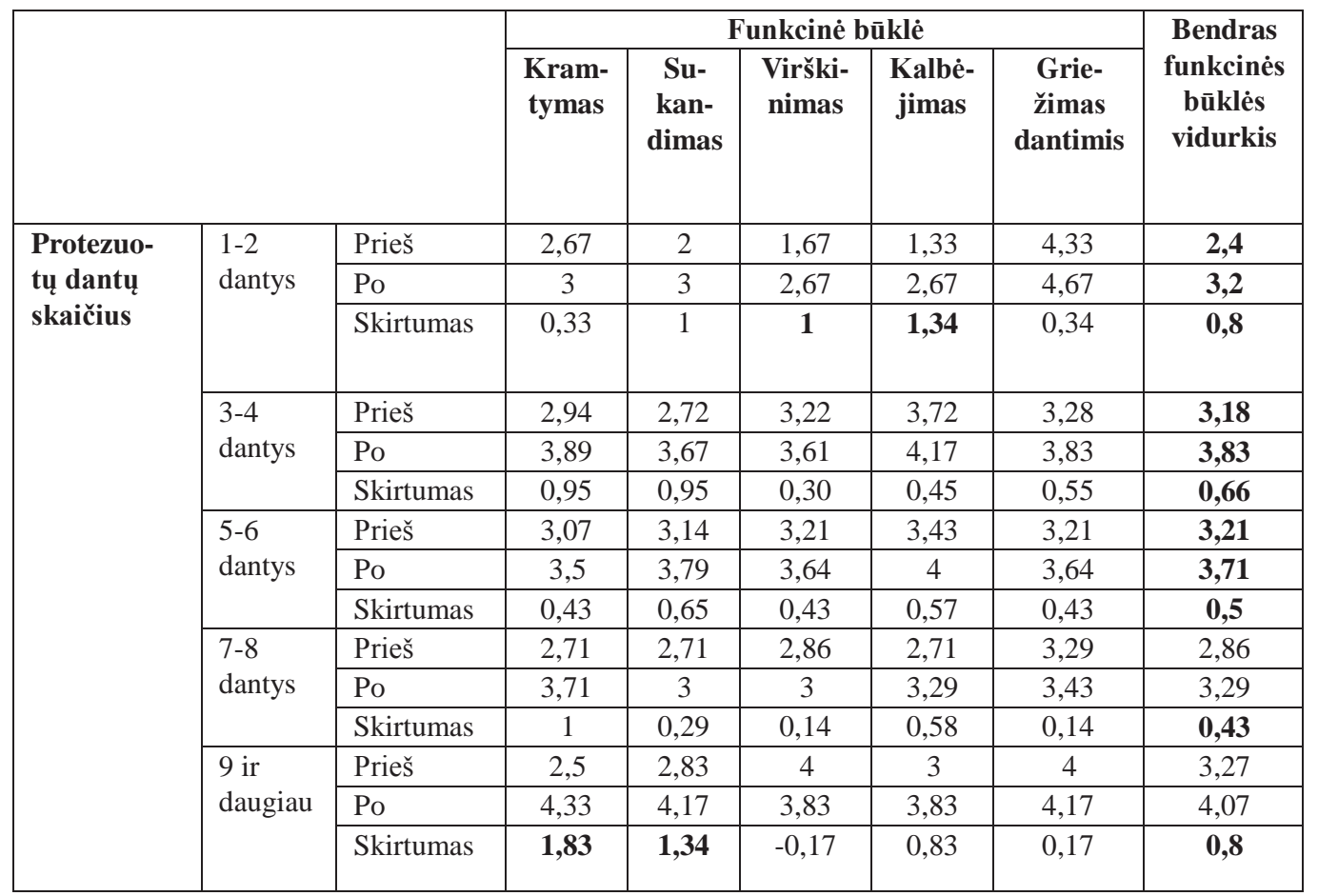


dyti, kas lėmè pasikeitimą. Šio tyrimo metu gautieji tyrimo rezultatai patvirtino jau ankščiau atliktu tyrimu rezultatus, kuriuose akcentuojama emocinès būklès kaitos svarba pacientui $[1,4,5]$. Straipsnyje pristatyto tyrimo metu taip pat buvo nustatyta, kad po estetinio protezavimo procedūros pacientai pradèjo labiau pasitikèti savimi, jie pradejo skirti didesnị dèmesị individualiai burnos higienai. Nors tyrimo rezultatai atskleidè, kad po estetinio protezavimo procedūros labiau pasikeite pacientu emocinè nei funkcinè būklè, vis dèlto lieka neaišku, kaip keisis pacientų požiūris ị funkcinę ir emocinę būklę laiko eigoje. Atliekant tolimesnius tyrimus šioje srityje siūloma tirti pacientu požiūrio ị funkcinès ir emocinès būklès kaitą priklausomai nuo laiko tarpo, kuris praeina nuo atliktos procedūros. Tikètina, kad emocinès būklès kaita gali būti susijusi su momentinio pasitenkinimo atlikta procedūra būsena, o praèjus ilgesniam laiko tarpui labiau išryškès funkcinès būklès kaitos svarba.

\section{Išvados}

1. Atlikto tyrimo rezultatai atskleide, kad po estetinio protezavimo procedūros pasikeitè pacientų emocinè būklè. Nustatyta, kad labiausiai pasikeitè pacientu pasitikèjimas savimi, atsirado pojūtis, jog gyvenimas yra geresnis ir pilnavertiškesnis. Tyrimo dalyviai pradèjo skirti daugiau dèmesio burnos higienai.

2. Vertinant pacientu funkcinès būklès pokyčius po estetinio protezavimo procedūros nustatyta, kad labiausiai pasikeite kramtymo funkcija bei sukandimas.

\section{Literatūra}

1. Dong J, Jin T, Cho H, Oh S. The esthetics of smile: a review of some recent studies // International Jurnal of Prosthodontics 1999; 12. (1): 9-19.

2. Freedman G. Contemporary esthetic dentistry // St. Louis: Missouri 2012.

3. Geissberger M. Esthetic dentistry in clinical practice. John Wiley \& Sons 2010.

4. Gurel G. Science and art of porcelain laminate veneers. Quintessence Publishing (IL) 2003.
5. Klages U, Bruckner A, Guld Y, Zentner A. Dental esthetic, orthodontic treatment, and oral- heath attitudes in young adults // American Journal of Orthodontics \& Dentofacial Orthopedics 2005; 128 (4): 442- 449.

http://dx.doi.org/10.1016/j.ajodo.2004.05.023

6. Lakshmi S. Preclinical Manual of Prosthodontics. Elsevier Health Sciences 2014.

7. Shen J, Kosmaš T. Advanced ceramics for dentistry // Whatham. USA, 2014.

8. Thylstrup A, Fejerskov O. Clinical appearance of dental fluorosis in permanent teeth in relation to histologic changes // Community Dentistry and oral epidemiology 2006, 6 (6): 315-328.

http://dx.doi.org/10.1111/j.1600-0528.1978.tb01173.x

\section{PATIENTS EMOTIONAL AND FUNCTIONAL CONDITIONAL CHANGE AFTER AESTHETIC RESTORATIONS OF TEETH}

J. Liškutė, R. Tamulienė, D. Mačiulienė

Key words: aesthetic restorations of teeth, emotional state, functional status.

Summary

The aim of the study: The aim of this research was to set patients emotional and functional conditions change after aesthetic restorations of teeth.

Methods and research participants: The study involved 48 patiens after aesthetic restorations of teeth procedure. Written survey (questionnaire) data collection method has been used.

Results: Research showed that patients emotional and functional status changed after aesthetic restorations procedure. According to the respondents opinion, emocional state changed more than functional status. The results of the research showed that patients felt more self- confident, positive and happy after aesthetic restorative procedure. Also the approach to oral hygiene changed, the respondents took more care of their teeth. Functional status changed more than emotional status. Mostly after procedure changed patients biting and chew.

Correspondence to: daiva.maciuliene@go.kauko.lt

Gauta 2015-11-30 